\title{
The Effects of Aerobic and Anaerobic Training Programs Applied to Elite Wrestlers on Body Mass Index (BMI) and Blood Lipids
}

\author{
Nurcan Demirel ${ }^{1}$, Serhat Özbay ${ }^{2}$, Fatih Kaya ${ }^{3}$ \\ ${ }^{1}$ Atatürk University, Faculty of Sport Sciences, Department of Sport Health Sciences, Erzurum, Turkey \\ ${ }^{2}$ Atatürk University, The Graduate School of Health Sciences, Department of Sport Health Sciences, Erzurum, Turkey \\ ${ }^{3}$ Erzincan University, Faculty of Education, Department of Physical Education and Sports Teaching, Erzincan, Turkey \\ Correspondence: Nurcan Demirel, Atatürk University, Faculty of Sport Sciences, Department of Sport Health Sciences, \\ Erzurum, Turkey.
}

Received: January 28, 2018

Accepted: March1, 2018

Online Published: March 6, 2018

doi:10.11114/jets.v6i4.3085

URL: https://doi.org/10.11114/jets.v6i4.3085

\begin{abstract}
The purpose of this study is to analyse the effects of aerobic and anaerobic training programs applied to elite wrestlers on body mass index (BMI) and blood lipids. 20 elite wrestlers, whose average age is (experimental group; 15.20 \pm 4.61 , $\mathrm{n}=10$ ), control group; $15.90 \pm 2.08, \mathrm{n}=10$ ), participated in the study and they were randomly divided into two groups. Strength and endurance training programme based on "one day aerobic, one day anaerobic" principles was applied to the experimental group six days a week for eight weeks. The control group went on doing normal routine wrestling technical training. Before and after eight-week training program, BMI, Triglyceride, HDL-C, VLDL, Cholesterol, LDL blood values were taken from the experimental and the control group by body analyser. According to the results of the study, none of the blood lipid indicators of the control group did significantly changed from pretest to posttest. ( $p>0.05$ ). However, HDL-C, cholesterol and LDL values from blood lipids indicators of the experimental group changed significantly from pretest to posttest. $(\mathrm{p}<0.05)$. There were no significant changes in body mass index $(\mathrm{BMI})$, Triglyceride and VLDL. As a result, this study revealed that there was no significant difference in the control group which did exercise routinely, while the training programme with changeable type and volume made significant differences in the experimental group.In statistical analyses, paired- samples $t$ test was used for intra-group comparisons, and independent sample $t$ test was used for inter-group comparisons. The significance level was determined as $\mathrm{p}<0.05$. For all the values, mean and standard deviation were used.
\end{abstract}

Keywords: wrestling, aerobic exercise, anaerobic exercise, BMI, blood lipids

\section{Introduction}

In today's world, the fact that people live sedentary lifestyles because of technological advances and have bad eating habits lead to obesity and hormonal imbalance, which can cause fatal results. Fighting against obesity is the first health priority of the world today. Obesity caused by sedentary lifestyle and malnutrition, and the problems in blood lipids which negatively affect cardiovascular system threaten human generation seriously. It has become essential to live an active lifestyle which includes regular exercise to prevent negative blood and body fattening.

\section{Relevant Literature}

The effect of exercise on biochemical parameters has been an ongoing research area. That exercise positively affected carbohydrate and lipid metabolism, and caused a reduction in body mass, fat reservoir, total cholesterol and triglycerides was found in previous studies (Tran \& Weltman, 1985). It is hard to think anaerobic and aerobic systems are independent of each other during exercise. As physiologic systems, they are independent components; however, they are closely associated with each other in an activity. The effects of acute or long-term different exercise programmes on biochemical parameters have been examined by a number of researchers (Tran \& Weltman, 1985). The generally accepted opinion regarding exercise and plasma lipid levels is that regular exercise has positive effects on blood lipid levels. A number of studies have shown that regular, long-term and moderate-intensity aerobic exercise decreases plasma lipid levels such as triglycerides (TG), low density lipoprotein- cholesterol (LDL-C), and total cholesterol, but increases the levels of high density lipoprotein- cholesterol (HDL-C) (Lemura \& Amdreacci, 2000; Koçyiğit et al. 2011). 
It is stated that regular exercise affects lipid metabolism and changes plasma lipid and lipoprotein levels. However, it is also reported that these positive effects of regular exercise are at different levels according to gender and the sport type (Ağırbaş et al. 2009). Considering the previous studies, it can be said that the effect of aerobic exercise programmes or of monotype exercise on blood lipids have been mostly examined. For this reason, in this study, it is aimed to examine the effect of aerobic and anaerobic exercise programmes on blood lipid profiles and body mass index of trained athletes.

\section{Methods}

\subsection{Participants and Procedure}

20 elite wrestlers, aged between 12-25, volunteered to participate in this study. All the participants were informed verbally and in writing of the nature and the purpose of the study. The wrestlers who had a chronic disease or lipid metabolism disorder were not included in the study. The wresters were randomly divided into two groups of experimental and control ( $\mathrm{n}=10$ per group). The experimental group was applied a 8-week training programme (an aerobic exercise on one day and an anaerobic exercise on another for 6 days) with the guidance of a coach, while the control group went on their weekly routine wrestling technique training programme. Venous blood samples and body mass index (BMI) of the wrestlers were collected with body composition analyser (Tanita Corporation) before and after the applied training. These blood samples were centrifuged under suitable conditions to collect serum samples. The obtained serum was stored at $-80^{\circ} \mathrm{C}$ until anaylsis. Glukose, triglycerides, HDL-C, VLDL, Cholesterol, LDL levels were analysed with spectrophotometric method by using the analyser, Beckman Coulter, AU 5800 (Beckman Coulter, CA, USA).

\section{Data Analyses}

In statistical analyses, paired- samples $t$ test was used for intra-group comparisons, and independent sample $t$ test was used for inter-group comparisons. The significance level was determined as $\mathrm{p}<0.05$. For all the values, mean and standard deviation were used.

\section{Results}

Physical characteristics of the wrestlers participated in the study are shown in Table 1.

Table 1. Physical Characteristics of Experimental and Control Group Mean (Ss)

\begin{tabular}{llll}
\hline Group & Age (year) & Height (cm) & Body Weight $\mathbf{( k g )}$ \\
\hline $\begin{array}{l}\text { Experimental } \\
\mathrm{n}=10\end{array}$ & $15.20(4.61)$ & $157.10(15.98)$ & $52.57(18.74)$ \\
$\begin{array}{l}\text { Control } \\
\mathrm{n}=10\end{array}$ & $15.90(2.08)$ & $166.20(12.80)$ & $56.84(11.14)$ \\
\hline
\end{tabular}

BMI and serum lipid levels of experimental group before and after the training are shown in Table 2.

Table 2. Changes in Blood Lipids from Pre-Test to Post-Test in Experimental Group

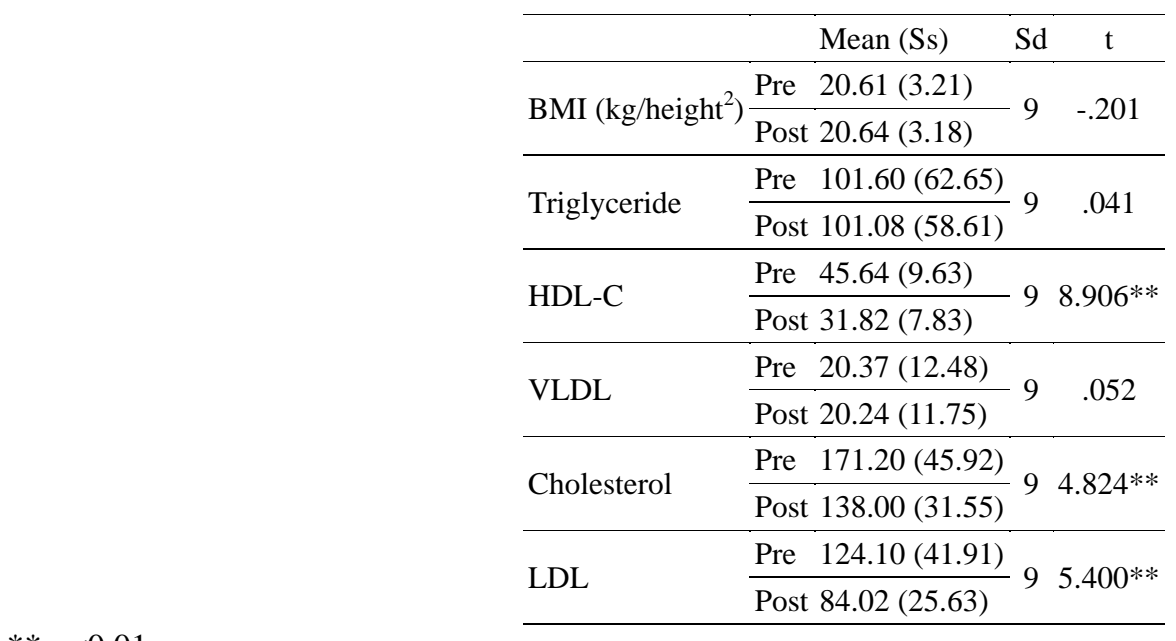

$* * \mathrm{p}<0.01$

HDL-C, cholesterol and LDL values of the experimental group significantly changed from pre-test to post-test $(\mathrm{p}<0.05)$. There were no significant changes in body mass index, glucose, triglycerides and VLDL values ( $p>0.05)$. Accordingly, HDL-C, cholesterol and LDL values of the experimental group significantly decreased from pre-test to post-test.

BMI and serum lipid levels of control group before and after the training are shown in Table 3. 
Table 3. Changes in Blood Lipids from Pre-Test to Post-Test in Control Group

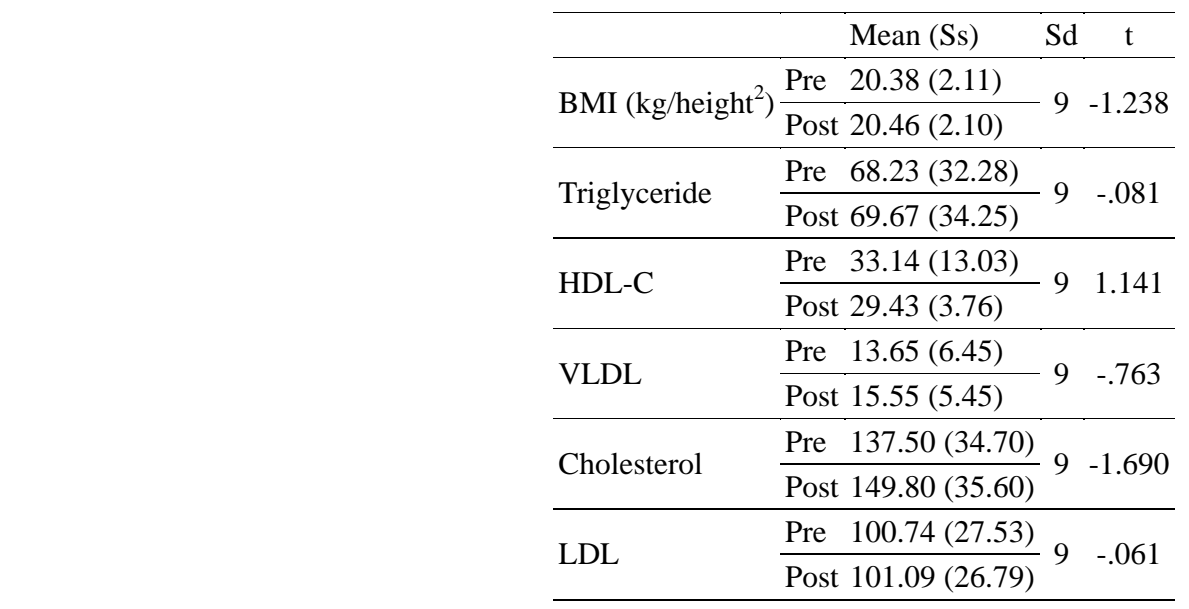

$\mathrm{p}>0.05$

None of the blood lipid indicators of the control group significantly changed from pre-test to post-test ( $p>0.05)$.

\section{Discussion}

Physical activity and exercise habit contribute to prevent obesity, cardiovascular diseases, diabetes and some other chronic diseases and to lead a healthy lifestyle. Exercise and physical activity are at the top of the treatment options list to prevent hyperlipidemia, one of the significant risk factors for cardiovascular diseases. The positive effect of regular, $\log$-term and moderate-intensity aerobic exercise on blood lipid levels was examined in a number of study (Lemura \& Amdreacci, 2000; Koçyiğit et al. 2011). In this study, it was aimed to evaluate the effect of long-term aerobic and anaerobic exercise on blood lipids and body mass index. As a result of the study, it was found that the blood lipid indicators, HDL-C, cholesterol and LDL values of the experimental group changed by significantly decreasing from pre-test to post-test ( $<<0.05)$, but there were no significant changes in body mass index, glucose, triglyceride and VLDL ( $p>0.05$ ). However, when the effect of endurance exercise training on body composition was examined in literature, it was found that at the end of the applied trainings, there were significant decreases in total body weight, body fat percentage, body mass index and skinfold thickness measurements, while there were significant increases in body density and lean body mass (Gökdemir et al. 2007; Patlar et al. 2003; Trapp et al. 2008). Similar to the findings of this study, it was found that continuous and interval training programmes, which were applied regularly three times a week for eight weeks had no effect on body weight, body fat percentage and anaerobic strength values (Yüksel et al. 2007). Votruba et al. (2000) stated in their work that neither the type nor the amount of exercise, except for endurance exercise, had a significant effect on weight loss. In this study, there were no significant increases in BMI values. The results obtained in terms of BMI values were not similar to the previous studies in literature. There are some findings showing that there were no changes in BMI values at the end of the training programmes (Büyükyazı et al. 2008; Savucu et al. 2006; Uğraş et al. 2002). Contrary to these results, there are also some findings showing that there were decreases in BMI values (Çolakoğlu \& Karacan, 2006; Çolakoğlu \& Şenel, 2003; Lakka et al. 2004; Yalın et al. 2001; Wong et al. 2008). This change in BMI values was considered to be caused by the increase in body weight. In their study with women, Çolakoğlu \& Şenel, (2003) found that there was an increase in body mass index, resting heart rate and LDL-C values, and an increase in HDL-C values after 8-week exercise training programme. There was a decrease in total cholesterol values, but it was not found statistically significant. There was an increase in triglyceride levels although they expected a decrease. Triglycerides' being blood lipids that are formed with nutrition was considered as the possible cause of this increase. The findings of this study mostly overlap with our findings. Reviewing the literature, we see that there are some researches that found there were no changes in cholesterol or total cholesterol levels by exercise (Wooten et al. 2008; Turgut et al. 1998; Uğraş \& Savaş, 2004; Büyükyazı et al. 2008; Çolakoğlu \& Şenel, 2003; Şekeroğlu et al. 1997). Besides these results, there are some researches supporting the findings of the present study (İmamoğlu et al. 2017; Kurt, 2006; Tran et al. 1983; Enger et al., 1980; Yalın et al. 2001; Lakka et al. 2004).

In the current study, it was found that the cholesterol and LDL values were significantly lower.

In this study, although cholesterol and LDL values significantly decreased, there was not an increase but a significant decrease in HDL-C level. In literature, there are a great number of studies showing significant increases in HDL-C values after exercise (Kurt, 2006; Şekeroğlu et al. 1997; Çolakoğlu \& Şenel, 2003; İmamoğlu et al. 2017; Tran et al. 1983; Enger et al. 1980; Turgut et al. 1998). On the other hand, there are some studies claiming there were no changes after exercise (Uğraş \& Savaş, 2004, Büyükyazı et al. 2008; Lakka et al. 2004). The number of studies which found a decrease in HDL-C values after exercise, as in this study, is limited. Some researchers stated that changes in lipoproteins varied by physical 
condition and exercise intensity level (Wooten et al. 2008; Kim et al. 2001; Crouse et al. 1995). Nicklas et al. (1997) related the effect of exercise on HDL-C to the weight of the individual, body fat distribution, the duration and intensity of the exercise, and whether there was weight loss or not by exercise. In another study, it was claimed that 18-week low and high intensity exercise had no effect on making significant changes in HDL-C values of young men whose blood lipid level was low (Gaesser \& Rich, 1984). Furthermore, the fact that lifestyles of individuals had an effect on HDL-C values was presented by some studies. In another study, it was found that smoking decreased the HDL-C values of women by $6,7 \%$ and of men by 3,3\% and alcohol consumption increased the values by 28,6\% and 50,1\% respectively (Ellison et al. 2004).

Comparing the LDL-C and VLDL-C values in this study, we found that there was a significant relation between the exercises and LDL-C, while there were no significant changes in VLDL-C. There are previous studies showing that there were no significant changes in LDL-C levels by exercise (Turgut et al. 1998; Büyükyazı et al. 2008; Şekeroğlu et al. 1997). There are also some studies similar to the current study, which showed decreases in LDL-C levels (Kurt, 2006; Çolakoğlu \& Şenel, 2003; İmamoğlu et al. 2017; Tran et al. 1983; Enger et al. 1980; Yalın et al. 2001; Lakka et al. 2004). Similar findings were obtained in terms of VLDL-C values. Similar to the present study, there are a number of studies showing that the changes in VLDL values caused by exercise were not significant (Lakka et al. 2004; Williams et al. 1989). There are some studies which found that VLDL-C value decreased by exercise (Turgut et al. 1998). Gaesser \& Rich (1984) claimed that 18-week low and high intensity exercises had no effect on making significant changes in LDL-C, HDL-C/ LDL-C values of young men whose blood lipid level was low.

As a result of this study, aerobic and anaerobic training programmes for the wrestlers had no significant change in BMI, glucose, triglyceride and VLDL-C values, but caused significant changes in cholesterol, LDL and HDL-C values. This study showed the positive results of anaerobic exercise done together with aerobic exercise in terms of blood lipids. According to the findings of the study, it can be said that doing aerobic exercise and anaerobic exercise together can make positive effect on blood lipids.

\section{References}

Ağırbaş, Ö., Kishalı, N. F., \& Çolak, M. (2009). The Effects of Body Composition on Serum Lipid and Lipoprotein Levels in Male Handball Players During Competition Period., Erzincan University Journal of Science and Technology, 2(2), 133-151.

Büyükyazı, G., Ulman, C., Taneli, F., Aksoy, D., \& T1kız, H. (2008). Effects of Walking on Serum Lipids, MMP-9 and TIMP-1 in Post-Menopausal Women. In 10th International Sport Congress, Bolu, Turkey.

Çolakoğlu, F. F., \& Karacan, S. (2006). The Effects of Aerobic Exercise in some Physiological Parameters in Young and Middle Aged Women. Kastamonu Ĕgitim Dergisi, 14(1), 277-284.

Çolakoğlu, F., \& Şenel, Ö. (2003). The Effects of 8 Weeks Aerobic Exercise Program on Body Composition and Blood Lipids of Middle Aged Sedentary Females. Ankara Üniversitesi Beden Eğitimi ve Spor Bilimleri Dergisi, 1(1), 56-61.

Crouse, S. F., O'Brien, B. C., Rohack, J. J., Lowe, R. C., Green, J. S., Tolson, H. O. M. E. R., \& Reed, J. L. (1995). Changes in Serum Lipids and Apolipoproteins After Exercise in Men With High Cholesterol: Influence of Intensity. Journal of Applied Physiology, 79(1), 279-286. https://doi.org/10.1152/jappl.1995.79.1.279

Ellison, R. C., Zhang, Y., Qureshi, M. M., Knox, S., Arnett, D. K., \& Province, M. A. (2004). Lifestyle Determinants of High-Density Lipoprotein Cholesterol: The National Heart, Lung, and Blood Institute Family Heart Study. American heart journal, 147(3), 529-535. https://doi.org/10.1016/j.ahj.2003.10.033

Enger, S. C., Strømme, S. B., \& Refsum, H. E. (1980). High Density Lipoprotein Cholesterol, Total Cholesterol and Triglycerides in Serum After a Single Exposure to Prolonged Heavy Exercise. Scandinavian journal of clinical and laboratory investigation, 40(4), 341-345. https://doi.org/10.3109/00365518009092653

Gaesser, G. A., \& Rich, R. C. (1984). Effects of High-and Low-Intensity Training on Aerobic Capacity. Medicine and Science in Sports and Exercise, 16(3), 269-274. https://doi.org/10.1249/00005768-198406000-00012

Gökdemir, K., Koç, H., \& Yüksel, O. (2007). Effects of Aerobic Training Program on Respiration Circulation and Body Fat Ratio of University Students. Egzersiz, 1, 145-149.

İmamoğlu, O., Altun, P., Çebi, M., \& Kishalı, N. F. (2017). The Effect of Aerobic Exercise and Weight-Lifting Plus Aerobic Exercise on Blood Pressure and Blood Parameters in Sedentary. Europen Journal of Physical Education and Sport Science, 3(1).

Kim, J. R., Oberman, A., Fletcher, G. F., \& Lee, J. Y. (2001). Effect of Exercise Intensity and Frequency on Lipid Levels in Men with Coronary Heart Disease: Training Level Comparison Trial. The American journal of cardiology, 87(8), 942-946. https://doi.org/10.1016/S0002-9149(01)01425-4

Koçyiğit, Y., Aksak, M. C., Atamer, Y., \& Aktaş, A. (2011). The Effect of Vitamin C Application on Liver Enzymes and 
Plasma Lipid Levels in Footballers and Basketball Players. Journal of Clinical and Experimental Investigations, 2(1). https://doi.org/10.5799/ahinjs.01.2011.01.0034

Kurt, U. (2006). The Examination of some Physiological and Blood Parameters of the A2 Volleyball League Samsun D. S. İ. Sports Male Volleyball Team in Respect of the Seasons. On Dokuz Mayls Üniversitesi, Sağllk Bilimleri Enstitüsü, Beden Eğitimi ve Spor Ana Bilim Dall, Yüksek Lisans Tezi, Samsun.

Lakka, H. M., Tremblay, A., Després, J. P., \& Bouchard, C. (2004). Effects of Long-Term Negative Energy Balance with Exercise on Plasma Lipid and Lipoprotein Levels in Identical Twins. Atherosclerosis, 172(1), 127-133. https://doi.org/10.1016/j.atherosclerosis.2003.09.012

Lemura, L. M., von Duvillard, S. P., Andreacci, J., Klebez, J. M., Chelland, S. A., \& Russo, J. (2000). Lipid and Lipoprotein Profiles, Cardiovascular Fitness, Body Composition, and Diet During and After Resistance, Aerobic and Combination Training in Young Women. European journal of applied physiology, 82(5-6), 451-458. https://doi.org/10.1007/s004210000234

Nicklas, B. J., Katzel, L. I., Busby-Whitehead, J., \& Goldberg, A. P. (1997). Increases in High-Density Lipoprotein Cholesterol with Endurance Exercise Training are Blunted in Obese Compared with Lean Men. Metabolism, 46(5), 556-561. https://doi.org/10.1016/S0026-0495(97)90194-3

Patlar, S., Sanioğlu, A., Kaplan, T., \& Polat, Y. (2003). Effect of Continual Running and Game Formation on Endurance Parameters on Footballers. SÜ Beden Eğitimi ve Spor Bilim Dergisi, 5(1-2), 10-17.

Savucu, Y., Sirmen, B., İnal, S., Karahan, M., Erdemir, İ. (2006). Determination the Effects of Basketball Training to the Physical Fitness of People with Mental Disabilities. Firat Üniversitesi Sağllk Bilimleri Dergisi, 20(2), 105-113.

Şekeroğlu, M. R., Recep Aslan, M. T., \& Kara, M. (1997). Effects of Acute Exercise and Physical Training on Serum Apolipoproteins and Lipids in Sedentary Men. Genel TiP Derg, 7(1).

Tran, Z. V., \& Weltman, A. (1985). Differential Effects of Exercise on Serum Lipid and Lipoprotein Levels Seen with Changes in Body Weight: A Meta-Analysis. Jama, 254(7), 919-924. https://doi.org/10.1001/jama.1985.03360070057023

Tran, Z. V., Weltman, A., Glass, G. V., \& Mood, D. P. (1983). The Effects of Exercise on Blood Lipids and Lipoproteins. Medicine and Science in Sport and Exercise, 15(5), 392-402. https://doi.org/10.1249/00005768-198315050-00009

Trapp, E. G., Chisholm, D. J., Freund, J., \& Boutcher, S. H. (2008). The Effects of High-Intensity Intermittent Exercise Training on Fat Loss and Fasting Insulin Levels of Young Women. International journal of obesity, 32(4), 684-691. https://doi.org/10.1038/sj.ijo.0803781

Turgut, G., Genç, O., \& Kaptanoğlu, B. (1998). Differences in Blood Lipid Fractions Between Sportsmen and Sedentary Individuals. SDÜ Tip Fakültesi Dergisi, 5(1).

Uğraş, A., \& Savaş, S. (2004). Effects of Aerobic Exercises on some Physiological Characteristics and Blood Lipids. Kastamonu Ĕ̈itim Dergisi, 293.

Votruba, S. B., Horvitz, M. A., \& Schoeller, D. A. (2000). The Role of Exercise in the Treatment of Obesity. Nutrition, 16(3), 179-188. https://doi.org/10.1016/S0899-9007(99)00264-6

Williams, P. T., Krauss, R. M., Vranizan, K. M., Albers, J. J., Terry, R. B., \& Wood, P. D. (1989). Effects of Exercise-Induced Weight Loss on Low Density Lipoprotein Subfractions in Healthy Men. Arteriosclerosis, Thrombosis, and Vascular Biology, 9(5), 623-632. https://doi.org/10.1161/01.ATV.9.5.623

Wong, P. C. H., Chia, M. Y. H., Tsou, I. Y. Y., Wansaicheong, G. K. L., Tan, B., Wang, J. C. K., ... Lim, D. (2008). Effects of A 12-Week Exercise Training Programme on Aerobic Fitness, Body Composition, Blood Lipids and C-Reactive Protein in Adolescents with Obesity. Ann. Acad. Med. Singapore, 37, 286-293.

Wooten, J. S., Biggerstaff, K. D., \& Anderson, C. (2008). Response of Lipid, Lipoprotein-Cholesterol, and Electrophoretic Characteristics of Lipoproteins Following a Single Bout of Aerobic Exercise in Women. European journal of applied physiology, 104(1), 19. https://doi.org/10.1007/s00421-008-0770-2

Yalın, S., Gök, H., \& Toksöz, R. (2001). The Effects of the Short-Term Regular Exercise-Diet Program on Lipid Profile in Sedentary Subjects. Anadolu Kardiyoloji Dergisi, 1(3), 1-18.

Yüksel, O., Koç, H., Özdilek, Ç., \& Gökdemir, K. (2007). The Effect of Continuous and Interval Training Programs on Anaerobic and Anaerobic Power of the University Students. Sağllk Bilimleri Dergisi, 16(3), 133-139.

\section{Copyrights}

Copyright for this article is retained by the author(s), with first publication rights granted to the journal.

This is an open-access article distributed under the terms and conditions of the Creative Commons Attribution license which permits unrestricted use, distribution, and reproduction in any medium, provided the original work is properly cited. 